\title{
Ekspresi Hypoxia-Inducible Factor-1 $\alpha$ menginduksi Ekspresi Eritropoietin Intraseluler, dan Vascular Endothelial Growth Factor pada Penderita Kanker Payudara dengan Anemia
}

\section{Hypoxia-Inducible Factor-1a Expression Induce Erythropoietin and Vascular Endothelial Growth Factor Expression on Breast Cancer with Anemia}

\author{
Muhammad Darwin $P^{1}$, Handono Kalim², Djoko Wahono $S^{2}$, Aru W Sudoyo ${ }^{3}$, Fatchiyah ${ }^{4}$ \\ ${ }^{1}$ Laboratorium IImu Penyakit Dalam Rumah Sakit Umum Daerah Ulin/Fakultas Kedokteran Unversitas Lambung \\ Mangkurat Banjarmasin \\ ${ }^{2}$ Laboratorium Ilmu Penyakit Dalam Fakultas Kedokteran Universitas Brawijaya Malang \\ ${ }^{3}$ Laboratorium IImu Penyakit Dalam Fakultas Kedokteran Universitas Indonesia Jakarta \\ ${ }^{4} J u r u s a n$ Biologi Fakultas MIPA Universitas Brawijaya Malang
}

\begin{abstract}
ABSTRAK
Anemia merupakan faktor prognostik independen untuk pertahanan hidup pasien kanker. Penurunan kapasitas oksigen pada darah dapat menyebabkan terjadinya kondisi hipoksia pada jaringan kanker. Hipoksia pada jaringan kanker dapat mengaktivasi faktor transkripsi hypoxia-inducible factor-1 $\alpha$ (HIF-1 $\alpha$ ) yang kemudian akan mentranskripsi banyak gen lain yang terlibat dalam invasi sel, angiogenesis, metabolisme anaerobik dan siklus sel, seperti gen eritropoietin (Epo) dan vascular endothelial growth factor (VEGF). Penelitian ini menggunakan sampel berupa 120 slide peraparat jaringan kanker payudara (60 anemi dan 60 non anemi) dengan melakukan pewarnaan secara imunofluoresen double staining untuk protein HIF1 $\alpha$ dengan VEGF dan Epo dengan EpoR. Sampel dibagi menjadi 2 kelompok, yaitu anemi $(H b 5,5-10,7)$ dan non anemi ( $\mathrm{Hb}$ 11-14,9). Hasil imunofluoresen di analisis dengan menggunakan Confocal Laser Scanning Microscope untuk mengetahui ekspresi protein target. Hasil dari penelitian menunjukkan bahwa tidak ada perbedaan yang signifikan pada ekspresi HIF1 $\alpha$ pada jaringan kanker penderita kanker payudara yang anemi dan non anemi namun sebaliknya ada perbedaan ekspresi VEGF yang signifikan $(p=0,013)$ antara pasien anemi $(754,4 \pm 316)$ dan non anemi $(555,1 \pm 276,9)$. Pada kelompok sampel anemi dan non anemi ada hubungan negatif antara Hb dan HIF1 $\alpha \quad(p=0,000 ; r=-0,522)$ dan hubungan positif antara HIF1 $\alpha$ dengan EPO ( $p=0,000 ; r=0,697)$, antara HIF1 $\alpha$ dengan VEGF ( $p=0,000 ; r=0,644)$, antara Epo dan VEGF $(p=0,001 ; r=0,433)$. Pada pasien kanker anemi dan non anemi telah terjadi kondisi hipoksia pada lingkungan tumornya sehingga menyebabkan ekspresi HIF1 $\alpha$ tidak berbeda signifikan namun hubungan HIF1 $\alpha$ dengan EPO dan VEGF sangat kuat.
\end{abstract}

Kata Kunci: Anemi, epo, HIF1 $\alpha$, hipoksia, VEGF

\section{ABSTRACT}

Anemia is an independent prognostic factor for survival of cancer patients. Decrease oxygen capacity in blood can lead to hypoxia in tumors. Hypoxia in the tumor environment can activate the transcription factor hypoxia-inducible factor-1 $\alpha$ (HIF-1 $\alpha$ ), which then transcribes many other genes involved in cell invasion, angiogenesis, anaerobic metabolism and cell cycle, such as erythropoietin (Epo) and vascular endothelial growth factor (VEGF). This study using 120 samples of breast cancer tissue (60 anemic and 60 non-anemic). Study using immunofluoresens double staining methods for HIF1 $\alpha$ protein with VEGF and Epo with the EpoR. Samples were divided into 2 groups: anemic (Hb 5,5-10,7) and non-anemic (Hb $11-$ $14,9)$. There was a significant difference of VEGF expression $(p=0,013)$ between patients anemic $(754,4 \pm 316)$ and nonanemic $(555,1 \pm 276,9)$. There were no significant difference of HIF1 $\alpha$ expression in both anemi and non-anemi breast cancer patients. In anemic and non anemic group there was a negative correlation between $\mathrm{Hb}$ and HIF1 $\alpha \quad(p=0.000, r=-$ $0,522)$ and positive correlation between HIF1 $\alpha$ and EPO ( $p=0,000 ; r=0,697)$, HIF1 $\alpha$ and VEGF $(p=0,000 ; r=0,644), E p o$ and $\operatorname{VEGF}(p=0,001 ; r=0,433)$. In anemic and non anemic cancer patients hipoxia condition has been occurred in tumour enviroment causing no significant different of HIF1 $\alpha$ expression, however there is a strong correllation between HIF $\alpha$ and Epo as well as HIF $\alpha$ and VEGF.

Keyword: Anemi, Epo, HIF1 $\alpha$, hypoxia, VEGF

Jurnal Kedokteran Brawijaya, Vol. 27 No. 2, Agustus 2012; Korespondensi: Muhammad Darwin P. Laboratorium Ilmu Penyakit Dalam Rumah Sakit Umum Daerah Ulin Banjarmasin, Jl. A. Yani No. 43 Banjarmasin Tel. (0511)3272932 Email: prenggonodarwin@yahoo.co.id 


\section{PENDAHULUAN}

Kanker payudara merupakan kanker terbanyak pada perempuan di seluruh dunia dengan angka kejadian yang terus meningkat baik di negara maju maupun di Asia (1). Pada tahun 2008 terdapat lebih dari 12,7 juta kasus kanker dan 7,6 juta diantaranya mengalami kematian. Kanker payudara merupakan kanker yang paling banyak menyebabkan kematian pada wanita, jumlah penderita kanker payudara adalah $23 \%$ dari angka total semua kejadian kanker dengan 14\% diantaranya mengalami kematian (2).

Anemia pada kanker dikaitkan dengan luaran klinis dan respon terapi yang lebih buruk (3). Pemberian erytrhopoietin stimulating agents (ESA) beberapa tahun terakhir sering dilakukan di klinik sebagai salah satu bentuk penatalaksanaan anemia. Penggunaannya pada kanker disetujui oleh United States Food and Drug Administration (FDA) pertama kali pada tahun 1993 (4).

Hipoksia di lingkungan mikro merupakan salah satu hallmark perkembangan tumor. Kondisi tersebut disebabkan penurunan suplai darah karena disorganisasi vaskulatur di sekitar sel-sel tumor yang berproliferasi. Meskipun hipoksia memiliki efek negatif terhadap proliferasi seluler (5), tetapi penyesuaian terhadap penurunan konsentrasi oksigen mengaktivasi transkripsi banyak gen lain yang terlibat dalam invasi sel, angiogenesis, metabolisme anaerobik dan siklus sel, melalui aktivasi hypoxia-inducible factor-1a (HIF-1 $\alpha)$ (6).

Aktivasi HIF1 $\alpha$ akan mentranskripsi beberapa gen target, salah satunya yaitu erythropoietin (Epo) (7). Erythropoietin bekerja melalui ikatannya dengan erythropoietin receptor (EpoR) di eritrosit, tetapi produksi EpoR tidak dicetuskan oleh HIF-1 $\alpha$. Selain Epo, faktor transkripsi HIF-1 $\alpha$ diketahui juga mempengaruhi angiogenesis melalui aktivasi transkripsi gen vascular endothelial growth factor (VEGF). Ekspresi VEGF umumnya dikaitkan dengan prognosis dan ketahanan hidup pasien kanker yang lebih buruk. Sebagai contoh, ekspresi HIF-1 $\alpha$ dan VEGF positif secara bermakna berhubungan dengan stadium tumor yang lebih tinggi, penyebaran ke kelenjar getah bening dan metastasis pada kanker kolorektal (8). Pada kanker serviks, ekspresi VEGF yang berlebihan dilaporkan berhubungan dengan ketahanan hidup yang lebih buruk (9).

Sejauh ini belum ada laporan tentang hubungan antara ekspresi HIF1 $\alpha$ dengan VEGF, Epo atau EpoR pada tumortumor yang hipoksik. Belum diketahui pula apakah perburukan terapi dengan ESA turut berpengaruh terhadap aktivitas angiogenesis intratumor atau tidak. Untuk mempelajari hal-hal tersebut pada populasi orang Indonesia, diperlukan studi dari pasien kanker di Indonesia mengenai ekspresi dari protein-protein tersebut pada jaringan kanker payudara.

\section{METODE}

Sampel

Penelitian ini menggunakan sampel berupa 120 slide peraparat jaringan kanker payudara (60 anemi dan 60 non anemi) dari Laboratorium Patologi Anatomik RS Dharmais Jakarta dan RS Saiful Anwar Malang berdasarkan kriteria inklusi dan eksklusi. Semua sampel yang di gunakan mempunyai data kadar $\mathrm{Hb}$ serta stadium kanker pasien yang terekam dalam Rekam Medis (RM). Dari masingmasing blok parafin jaringan kanker payudara di buat 4 slide preparat yaitu 1 preparat yang telah diwarnai hematoxylin eosin (HE) dan 3 preparat yang belum terwarnai. Slide preparat yang telah diwarnai hematoxylin eosin (HE) kemudian dibaca oleh 3 (tiga) ahli patologi anatomi RS Dharmais Jakarta dan RS Saiful Anwar untuk mengetahui keadaan histopatologi kanker.

\section{Analisis Imunofluoresens}

Penelitian dilakukan dengan analisis imunofluoresens secara double staining terhadap protein HIF1 $\alpha$ dan VEGF serta Epo dengan EpoR. Slide preparat direndam dalam xylol 2 kali 5 menit, kemudian direndam dalam etanol absolut selama 5 menit sebanyak 2 kali dan dilanjutkan dengan etanol $90 \%$ dan $70 \%$ masing-masing selama 5 menit. Selanjutnya preparat direndam dalam PBS 3 kali 5 menit, preparat dimasukkan dalam $10 \mathrm{mM}$ buffer sitrat $\mathrm{pH}$ 6) dan dipanaskan dalam microwave pada high temperature selama 10 menit. Preparat dan wadah selanjutnya dikeluarkan dari microwave dan ditunggu beberapa saat. Setelah itu, preparat dicuci dengan PBS 3 kali 5 menit, lalu di blocking menggunakan $2 \%$ susu skim overnight. Slide preparat kemudian di cuci kembali dengan PBS 3 kali 10 menit, dan ditetesi dengan antibodi primer anti-VEGF Rabbit Polyclonal (1:1000) dalam 2\% susu skim di suhu ruang selama 1 jam. Setelah itu, preparat dicuci lagi dengan PBS 3 kali 10 menit. Preparat lalu ditetesi dengan antibodi sekunder Mouse-anti Rabbit FITC Labeled (1:1500) selama satu jam dalam suhu ruang tanpa cahaya, kemudian di cuci dengan PBS 3 kali 10 menit dan di blocking kembali dengan menggunakan $2 \%$ susu skim overnignt. Slide preparat kemudian di cuci kembali dengan PBS 3 kali 10 menit, dan ditetesi dengan antibodi primer anti-HIF1 $\alpha$ Rabbit Polyclonal (1:1000) dalam 2\% susu skim di suhu ruang selama $1 \mathrm{jam}$. Setelah itu, preparat dicuci lagi dengan PBS 3 kali 10 menit. Preparat lalu ditetesi dengan antibodi sekunder Goat-anti Rabbit Rhodamin Labeled (1:1000) selama satu jam dalam suhu ruang tanpa cahaya, kemudian di cuci dengan PBS 3 kali 10 menit.

Proses pewarnaan secara imunohistokimia protein Epo dan EpoR hampir sama dengan proses pewarnaan HIF1 $\alpha$ dan VEGF, akan tetapi untuk pewarnaan Epo dan EpoR digunakan antibodi primer anti-EpoR Rabbit Polyclonal IgG (1:1000) dan anti-Epo Rabbit Polyclonal (1:1000) dalam $2 \%$ susu skim dengan antibodi sekunder yang digunakan adalah Mouse-anti Rabbit FITC Labeled (1:1500) dan Goat-anti Rabbit Rhodamin Labeled (1:1000) dalam $2 \%$ susu skim. Hasil pewarnaan imunofluoresen selanjutnya diamati dengan menggunakan Confocal Laser Scanning Microscope (perbesaran 400x) untuk mengamati ekspresi protein-protein target pada jaringan kanker payudara.

\section{HASIL}

Hasil penelitian menggambarkan peran kondisi anemia yang menyebabkan hipoksia pada prognosis kanker melalui aktifasi HIF1 $\alpha$. Secara kuantitatif disajikan perbedaan ekspresi masing-masing gen yaitu VEGF, Epo atau EpoR.

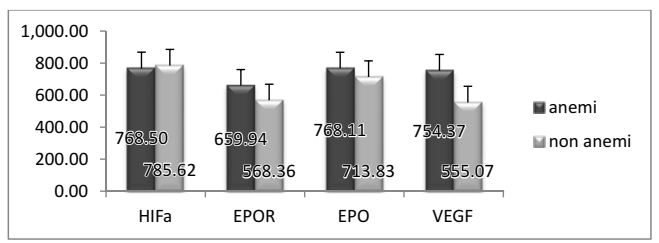

Gambar 1. Perbandingan ekspresi protein antara kelompok anemi dan non anemi. 
Berdasarkan hasil uji t berpasangan yang ditampilkan pada Gambar 1 menunjukkan bahwa ada perbedaan ekspresi VEGF yang sangat signifikan ditunjukkan dengan $\mathrm{Hb}(p=0,000), H I F \alpha(p=0,844)$, EpoR $(p=0,255)$, Epo $(p=0,437)$, VEGF $(p=0,013)$ antara kelompok sampel anemi $(754,4 \pm 316,6)$ dan non anemi $(555,1 \pm 276,9)$. Ekspresi HIF1 $\alpha$, Epo, dan EpoR diketahui tidak berbeda signifikan antara kelompok sampel anemi dengan kelompok sampel non anemi.
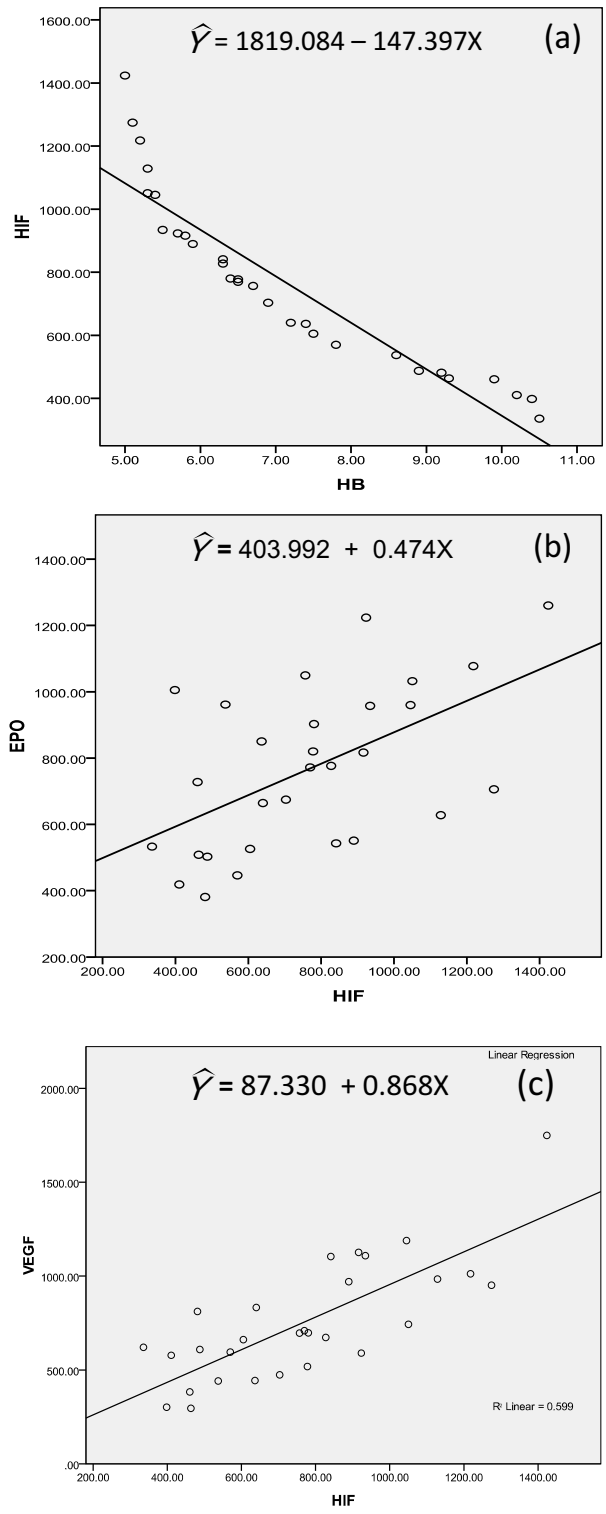

Gambar 2. Hubungan level Hb dengan ekspresi HIF1 $\alpha$ (a) dan hubungan ekspresi HIF1 $\alpha$ terhadap ekspresi Epo (b) dan VEGF pada kelompok anemi (c).

Berdasarkan hasil uji regresi, diketahui bahwa pada kelompok sampel anemi dan non anemi nilai koefisien pengaruh $\mathrm{Hb}$ terhadap $\mathrm{HIF1} \alpha(-0,5807)$ menunjukkan nilai negatif. Bila $\mathrm{Hb}$ meningkat maka HIF1 $\alpha$ menurun atau bila $\mathrm{Hb}$ menurun maka HIF1 $\alpha$ akan meningkat. Nilai koefisien pengaruh HIF1 $\alpha$ terhadap Epo $(+0,561)$ menunjukkan adanya pengaruh yang seiring. Bila ada peningkatan pada HIF1 $\alpha$ maka akan berpengaruh pada peningkatan Epo, demikian pula sebaliknya bila terjadi penurunan HIF1 $\alpha$ maka akan terjadi penurunan pada Epo. Nilai koefisien pengaruh HIF1 $\alpha$ terhadap VEGF menunjukkan nilai positif yaitu 0,774 yang berarti menunjukkan adanya pengaruh yang seiring. Bila ada peningkatan pada HIF-1 maka akan berpengaruh pada peningkatan VEGF, demikian pula sebaliknya.

Hasil uji korelasi menunjukkan bahwa ada hubungan yang cukup kuat dan sangat signifikan $(p=0,000)$ antara $\mathrm{Hb}$ dan HIF1 $\alpha$ dengan koefisian korelasi $(-0,522)$. Nilai korelasi menunjukkan bahwa ada hubungan yang berlawanan arah, bila $\mathrm{Hb}$ meningkat maka HIF1 $\alpha$ menurun atau bila $\mathrm{Hb}$ menurun maka HIF1 $\alpha$ akan meningkat pada kelompok sampel anemi dan non anemi. Ada hubungan yang signifikan $(p=0,025)$ antara $\mathrm{Hb}$ dan EpoR dengan koefisien korelasi $-0,291$. Nilai negatif menunjukkan ada hubungan yang berlawanan arah, $\mathrm{Hb}$ meningkat maka EpoR menurun atau bila $\mathrm{Hb}$ menurun maka EpoR akan meningkat pada kelompok sampel anemi dan non anemi.

Tabel 1 menunjukkan bahwa ada hubungan antara HIF1 $\alpha$ dengan Epo kuat dan signifikan ( $r=0,697 ; p=0,001)$. Demikian pula HIF1 $\alpha$ dengan VEGF menunjukkan bahwa ada hubungan yang sangat signifikan $(p=0,000)$ yang ditunjukkan dengan tingkat keeratan hubungan yang kuat yaitu 0,644. Keduanya menunjukkan nilai koefisien korelasi positif yang berarti ada hubungan yang seiring. Bila HIF1 $\alpha$ meningkat maka Epo dan VEGF juga akan meningkat dan sebaliknya bila HIF1 $\alpha$ menurun maka Epo dan VEGF juga akan menurun.

Tampak pula EpoR dengan Epo juga menunjukkan ada hubungan yang sangat bermakna $(p=0,001)$ dengan ditunjukkan nilai koefisien korelasi sebesar 0,439. Ada hubungan yang bermakna antara EPO dan VEGF yang ditunjukkan dengan tingkat korelasi sedang $(r=0,433$; $p=0,001$ ).

Tabel 1. Koefisien korelasi ekspresi HIF1 $\alpha$, VEGF, Epo, EpoR dan stadium kanker pada kelompok pasien anemi dan non anemi

\begin{tabular}{|c|c|c|c|}
\hline \multicolumn{2}{|c|}{ Variabel } & \multirow{2}{*}{$\begin{array}{c}\text { Koefisien korelasi } \\
-0,522\end{array}$} & \multirow{2}{*}{$\frac{p \text {-value }}{0,000}$} \\
\hline $\mathrm{Hh}$ & HIF1 $\alpha$ & & \\
\hline HD & EpoR & $-0,291$ & 0,025 \\
\hline \multirow{2}{*}{ HIF1 $\alpha$} & Epo & 0,697 & 0,000 \\
\hline & VEGF & 0,644 & 0,000 \\
\hline EpoR & Epo & 0,439 & 0,001 \\
\hline EpoR & \multirow{3}{*}{$\begin{array}{l}\text { Stadium } \\
\text { Kanker }\end{array}$} & $-0,068$ & 0,608 \\
\hline Epo & & $-0,066$ & 0,619 \\
\hline VEGF & & $-0,036$ & 0,786 \\
\hline
\end{tabular}

Keterangan: $p$-value $>0,05$ tidak ada hubungan yang bermakna, $p$-value $<0,05$ ada hubungan yang bermakna.

\section{DISKUSI}

Anemia merupakan masalah medis yang berpotensi besar mempengaruhi luaran klinis pasien kanker. Anemia juga dikaitkan dengan luaran klinis dan respons terapi yang lebih buruk $(3,10)$. Anemia dapat terjadi akibat penurunan produksi sel darah merah, peningkatan destruksi sel darah merah, berkurangnya sel darah merah di sirkulasi, atau kombinasi faktor-faktor tersebut (11). Kondisi lain yang dapat mempengaruhi terjadinya anemia adalah defisiensi 
besi, yang sering terjadi pada penderita kanker.

Pasien dengan anemia berat $(\mathrm{Hb}<8 \mathrm{~g} / \mathrm{dL})$ akan mengalami gejala-gejala seperti letargi, penurunan toleransi latihan, susah bernapas dan palpitasi. Pasien juga berisiko mengalami penurunan oksigenasi jaringan. Hemoglobin pada kadar 7-9 g/dL berhubungan dengan kondisi fatigue yang berat dan pasien akan mengalami perbaikan keluhan sesuai dengan peningkatan hemoglobin (12). Perbaikan tingkat energi akan terjadi sampai kadar hemoglobin mencapai 12-13 g/dL (13).

Berdasarkan hasil penelitian ini, diketahui bahwa ekspresi HIF1 $\alpha$ antara pasien kanker payudara anemi $(\mathrm{Hb}<10,7)$ dan non anemi $(10,7<\mathrm{Hb}<14,9)$ tidak berbeda nyata. Berdasarkan hasil pengujian klinis, ditemukan adanya hubungan langsung antara level $\mathrm{Hb}$ dengan nilai $\mathrm{pO}_{2}$ intratumor pada pasien kanker payudara (11). Nilai ratarata $\mathrm{pO}_{2}$ pada pasien dengan kadar $\mathrm{Hb}$ antara 8,5-14,7 $\mathrm{g} / \mathrm{dl}$ adalah sangat rendah yaitu 3-15 mmHg. Sebaliknya, nilai $\mathrm{pO}_{2}$ pada jaringan payudara normal ditemukan sangat tinggi, yaitu $52 \mathrm{mmHg}$ (12). Nilai $\mathrm{pO}_{2}$ antara 1-15 akan menyebabkan terjadinya perubahan proteome sel $(13,14)$, sedangkan nilai $\mathrm{pO}_{2}$ antara $10-20$ akan menyebabkan terikatnya marker hipoksia pada gen target transkripsi $(15,16)$. Penelitian ini menggunakan sampel dari pasien dengan level $\mathrm{Hb}$ antara 5,0-14,4. Diduga bahwa telah terjadi kondisi hipoksia pada jaringan kanker yang menyebabkan HIF1 $\alpha$ tetap di produksi baik pada kanker anemi anemi maupun non anemi.

Pada penelitian ini didapatkan bahwa level $\mathrm{Hb}$ mempunyai hubungan yang berbanding terbalik dengan HIF1 $\alpha$, yang artinya bahwa semakin tinggi level $\mathrm{Hb}$ maka ekspresi HIF1 $\alpha$ semakin rendah. Rendahnya level $\mathrm{Hb}$ berhubungan dengan rendahnya level $\mathrm{pO}_{2}$ jaringan. Hipoksia akan meningkatkan level HIF1 $\alpha$ pada semua tipe sel dan menurunkan degradasi HIF1 $\alpha$, faktor pertumbuhan, sitokin, dan molekul-molekul lainnya yang menstimulasi sintesis HIF1 $\alpha$ melalui aktivasi jalur phosphatidylinositol 3-kinase (PI3K) atau mitogenactivated protein kinase (MAPK) $(17,18)$.

Penelitian ini menemukan bahwa ekspresi VEGF pada jaringan pasien berbeda signifikan antara pasien anemi dengan non anemi. Diduga pada jaringan kanker baik pada pasien non anemi maupun non anemi telah terjadi kondisi hipoksia. Pada kondisi anemia $(\mathrm{Hb}<10,7)$ menyebabkan HIF1 $\alpha$ lebih aktif dalam mensintesis VEGF, sedangkan gen VEGF sendiri lebih sensitif dalam merespon HIF1 $\alpha$ sehingga level VEGF akan secara signifikan lebih tinggi pada pasien anemi daripada non anemi. Ekspresi mRNA VEGF dipicu oleh tekanan oksigen rendah salah satunya seperti pada kanker (19). Dari sekian banyak target gen HIF1, gen VEGF merupakan yang paling dominan dan berperan penting dalam proses neovaskularisasi tumor untuk menyediakan oksigen dan nutrisi yang cukup untuk propagasi dan metastasis tumor (20).

Keberadaan VEGF merupakan stimulator yang kuat untuk proses angiogenesis baik in vitro maupun in vivo, dan sudah diterima bahwa pada kondisi hipoksia ekspresi VEGF di mediasi oleh HIF1 $\alpha$. Gen VEGF mengandung satu HIF-1 binding site pada daerah regulatornya yang merupakan tempat penempelan HIF1 untuk menginisiasi proses transkripsi VEGF (21). Telah dilaporkan sebelumnya bahwa ekspresi HIF1 $\alpha$ berkorelasi secara langsung dengan ekspresi VEGF dan vaskularisasi tumor pada beberapa jenis tumor seperti kanker endometrium, kanker paru-paru, kanker otak, kanker kepala dan leher (22).

Penelitian ini menemukan bahwa peningkatan ekspresi HIF1a menyebabkan terjadinya peningkatan ekspresi VEGF, demikian pula sebaliknya bila terjadi penurunan ekspresi HIF1 $\alpha$ maka akan terjadi penurunan pada ekspresi VEGF. Dalam hal ini, HIF-1 merupakan faktor transkripsi penting yang memicu ekspresi gen $V E G F$, karena gen VEGF mengandung sejumlah HIF-1 $\alpha$ binding sites di bagian regulator transkripsinya (23). Kompleks HIF1 kemudian akan mengikat HRE di gen VEGF dan memicu transkripsi VEGF serta gen-gen lain yang berperan dalam angiogenesis pada tumor (24).

Penelitian yang dilakukan oleh Kuwai dkk (2003) pada jaringan kanker kolon menunjukkan bahwa kondisi hipoksia menyebabkan peningkatan produksi HIF1 $\alpha$. Peningkatan ekspresi HIF1 $\alpha$ tersebut juga berhubungan dengan peningkatan level mRNA VEGF. Analisis secara imunohistokimia juga menunjukkan adanya korelasi antara ekspresi HIF1 $\alpha$ dengan VEGF (25). Hasil dari penelitian ini semakin menguatkan fakta bahwa HIF1 $\alpha$ dan VEGF mempunyai hubungan yang berbanding lurus. Peningkatan ekspresi HIF1 $\alpha$ akan menyebabkan terjadinya peningkatan ekspresi VEGF.

Hasil penelitian menunjukkan bahwa peningkatan ekspresi HIF1 $\alpha$ akan berpengaruh pada peningkatan ekspresi Epo, demikian pula sebaliknya bila terjadi penurunan HIF maka akan terjadi penurunan ekspresi Epo. Hipoksia yang terjadi pada sel-sel kanker akan menyebabkan sel tersebut mengekspresikan protein hypoxia-inducible factor-1 (HIF-1) (7). HIF-1 berperan penting dalam memicu transkripsi gen-gen target, salah satunya adalah Epo (26). Penelitian dengan menggunakan berbagai jenis kultur sel kanker menunjukkan adanya ekspresi mRNA Epo pada semua kultur sel kanker tersebut, dan stimulasi produksi Epo pada kondisi hipoksia diduga merupakan mekanisme autokrin atau parakrin untuk proses pertahanan diri sel-sel kanker (27). Penelitian yang dilakukan oleh Acs dkk (2001) menunjukkan tingginya ekspresi Epo dan reseptornya pada jaringan tumor padat yang dianalisis secara imunohistokimia. Hal ini semakin memperkuat dugaan bahwa Epo dan reseptornya juga berperan dalam proses pertahanan diri sel-sel kanker.

Pada penelitian ini didapatkan bahwa ekspresi Epo dan EpoR mempunyai hubungan yang berbanding lurus. Peningkatan ekspresi Epo akan menyebabkan terjadinya peningkatan ekspresi EpoR. Dahulu diduga bahwa EpoR hanya terdapat pada sel-sel eritroid, tetapi kini telah diketahui bahwa EpoR terdapat di berbagai jenis sel noneritroid dan juga pada sel-sel tumor. Beberapa studi telah memperlihatkan ekspresi EpoR pada kultur sel tumor dan juga kanker primer. Tumor juga mengekspresikan transkrip mRNA sehingga memberi kesan terjadinya stimulasi pertumbuhan autokrin atau parakrin di sel-sel kanker. Ekspresi Epo pada sel-sel kultur tumor juga diinduksi oleh hipoksia (28).

Penelitian ini mengidentifikasi hubungan yang signifikan antara ekspresi EpoR terhadap Epo pada kelompok sampel non anemi dan kelompok sampel anemi dan non anemi. Berdasarkan data dari NCCN (2011), analisis terhadap 8 studi pada pasien kanker didapatkan adanya penurunan pertahanan hidup pada pasien kanker dengan level $\mathrm{Hb}>12$ $\mathrm{g} / \mathrm{dL}$ yang menerima terapi ESA. Risiko penurunan pertahanan hidup dan peningkatan progresivitas kanker 
tidak ditemukan ketika ESA diberikan pada pasien kanker dengan level $\mathrm{Hb}<12 \mathrm{~g} / \mathrm{dL}$. Hasil dari penelitian ini mendukung mendukung hal tersebut. Pada kelompok sampel non anemi (level $\mathrm{Hb}>11,9$ ) Epo dan EpoR berhubungan secara signifikan. Ketika pasien mendapatkan terapi ESA akan menyebabkan pengikatan ESA tersebut pada EpoR pembuluh darah ataupun pada sel kanker sehingga menyebabkan peningkatan progresivitas sel-sel kanker.

Berdasarkan hasil penelitian ini diketahui bahwa ekspresi Epo berhubungan dengan ekspresi VEGF. Penelitian yang dilakukan oleh Batra dkk (2003) mengatakan bahwa terdapat peningkatan produksi dan pelepasan faktor

\section{DAFTAR PUSTAKA}

1. McPherson K, Steel CM, and Dixon JM. Breast Cancer Epidemiology, Risk Factors, and Genetics. British Medical Journal. 2000; 321(7261): 624-628.

2. Ferlay J, Shin HR, Bray F, Forman D, Mathers C, and Parkin DM. Estimates of Worldwide Burden of Cancer in 2008: GLOBOCAN 2008. International Journal of Cancer. 2010; 127(12): 2893-2917.

3. Harper P and Littlewood T. Anaemia of Cancer: Impact on Patient Fatigue and Long-Term Outcome. Oncology. 2005; 69(2): 2-7.

4. Overgaard J, Hoff C, Sand Hansen H, et al. Randomized Study of Novel Erythropoiesis Stimulating Protein (Aranesp ${ }^{\circledR}$ ) for the Effect of Radiotherapy in Patients with Primary Squamous Cell Carcinoma of the Head and Neck (HNSCC)-the Danish Head and Neck Cancer Group DAHANCA 10. European Journal of Cancer. 2007; 5(6): 7.

5. Graeber TG, Peterson JF, Tsai M, Monica K, Fornace AJ $\mathrm{Jr}$, and Giaccia AJ. Hypoxia Induces Accumulation of P53 Protein, but Activation of a G1-Phase Checkpoint by Lowoxygen Conditions is Independent of P53 Status. Molecular and Cellular Biology. 1994; 14(9): 6264-6277.

6. Semenza GL. Targeting HIF-1 for Cancer Therapy. Nature Reviews Cancer. 2003; 3(10): 721-732.

7. Wang GL and Semenza GL. General Involvement of Hypoxia Inducible Factor 1 in Transcriptional Resresponse to Hypoxia. Proceedings of the National Academy of Sciences of the United States of America. 1993; 90(9): 4304-4308.

8. Cao D, Hou M, Guan YS, Jiang M, Yang Y, and Gou HF. Expression of HIF-1 Alpha and VEGF in Colorectal Cancer: Association with Clinical Outcomes and Prognostic Implications. BMC Cancer. 2009; 9: 432.

9. Goncharuk IV, Vorobjova LI, Lukyanova NY, and Chekhun VF. Vascular Endothelial Growth Factor Expression in Uterine Cervical Cancer: Correlation with Clinicopathologic Characteristics and Survival. Experimental Oncology. 2009; 31(3): 179-181.

10. Lee WR, Berkey B, Marcial V, et al. Anemia is Associated with Decreased Survival and Increased Locoregional Failure in Patients with Locally Advanced Head and Neck Carcinoma: A Secondary Analysis of RTOG 85-27. International Journal of Radiation angiogenesis, VEGF, dan PLGF karena terapi dengan erytrhopoietin pada dosis yang tinggi (29). Penelitian ini mendukung hasil dari penelitian tersebut, sehingga untuk ke depannya perlu lebih diperhatikan lagi dalam penggunaan ESA untuk terapi pasien kanker.

Hasil penelitian ini menunjukkan bahwa level $\mathrm{Hb}$ berpengaruh negatif terhadap ekspresi HIF-1. HIF-1 merupakan faktor transkripsi yang mampu mensintesis protein Epo dan VEGF. Ekspresi HIF-1 berkorelasi positif dengan ekspresi Epo dan VEGF. HIF-1 lebih aktif dalam menstimulus transkripsi gen VEGF pada pasien dengan anemi.

Oncology*Biology* Physics. 1998; 42(5): 1069-1075.

11. Hurter B and Bush NJ. Cancer-Related Anemia: Clinical Review and Management Update. Clinical Journal of Oncology Nursing. 2007; 11(3): 349-459.

12. Glaspy J. Anemia and Fatigue in Cancer Patients. Cancer. 2001; 92(6): 1719-1724.

13. Charles C, George D, Glaspy J, et al. Identifying Hemoglobin Levels for Optimal Quality of Life: Results of an Incremental Analysis. American Society of Clinical Oncology. 1999; 18: 574(a).

14. Vaupel P and Mayer A. Hypoxia in Cancer: Significance and Impact on Clinical Outcome. Cancer Metastasis Reviews. 2007; 26(2): 225-39.

15. Brahimi-Horn, Mazure N, and Pouyssegur J. Signalling Via the Hypoxia-Inducible Factor-1alpha Requires Multiple Posttranslational Modifications. Cellular Signalling. 2005; 17(1): 1-9.

16. Srinivas V, Zhang LP, Zhu XH, and Caro J. Characterization of an Oxygen/Redox-Dependent Degradation Domain of Hypoxia-Inducible Factor Alpha (HIF-Alpha) Proteins. Biochemical and Biophysical Research Communications. 1999; 260(2): 557-561.

17. Fukuda R, Hirota K, Fan F, Jung YD, Ellis LM, and Semenza GL. Insulin-Like Growth Factor 1 Induces Hypoxia-Inducible Factor 1-Mediated Vascular Endothelial Growth Factor Expression, which is Dependent on MAP Kinase and Phosphatidylinositol 3Kinase Signaling in Colon Cancer Cells. The Journal of Biological Chemistry. 2002; 277(41): 38205-38211.

18. Lahiri S, Semenza GL, and Prabhakar NR. Oxygen Sensing: Responses and Adaptation to Hypoxia. New York: Marcel Dekker Inc.; 2003; p. 95-108.

19. Dor Y, Porat R, and Keshet E. Vascular Endothelial Growth Factor and Vascular Adjustments to Pertubations in Oxygen Homeostasis. American Journal of Physiology-Cell Physiology. 2001; 280(6): C1367-1374.

20. Maxwell PH, Dachs GU, Gleadle JM, et al. HypoxiaInducible Factor-1 Modulates Gene Expression in Solid Tumors and Influences Both Angiogenesis and Tumor Growth. Proceedings of the National Academy of Sciences of the United States of America. 1997; 94: 8104-8109.

21. Yoshimura H, Dhar DK, Kohno H, et al. Prognostic 
Impact of Hypoxia-Inducible Factors 1alpha and 2alpha in Colorectal Cancer Patients: Correlation with Tumor Angiogenesis and Cyclooxygenase-2 Expression. Clinical Cancer Research. 2004; 10(24): 8554-8560.

22. Schindl M, Schoppmann SF, Samonigg $\mathrm{H}$, et al. Overexpression of Hypoxia-Inducible Factor 1alpha is Associated with an Unfavorable Prognosis in Lymph Node-Positive Breast Cancer. Clinical Cancer Research. 2002;8(6): 1831-1837.

23. Forsythe $\mathrm{JA}$, Jiang $\mathrm{BH}$, lyer $\mathrm{NV}$, et al. Activation of Vascular Endothelial Growth Factor Gene Transcription by Hypoxia-Inducible Factor 1. Molecular and Cellular Biology. 1996;16(9): 46044613.

24. Semenza GL. Hypoxia and Cancer. Cancer Metastasis Reviews. 2007; 26: 223-224.

25. Kuwai T, Kitadai Y, Tanaka S, et al. Ekspression of
Hypoxia-Inducible Factor-1 $\alpha$ is Associated with Tumor Vascularization in Human Colorectal Carcinoma. International Journal of Cancer. 2003; 105(2): 176181.

26. Semenza G. Signal Transduction to Hypoxia-Inducible Factor 1. Biochemical Pharmacology. 2002; 64(5-6): 993-998.

27. Laugsch M, Metzen E, Svensson T, Depping R, and Jelkmann W. Lack of Functional Erythropoietin Receptors of Cancer Cell Lines. International Journal of Cancer. 2008; 122(5): 1005-1011.

28. Acs G, Acs P, Beckwith SM, et al. Erythropoietin and Erythropoietin Receptor Expression in Human Cancer. Cancer Research. 2001; 61(9): 3561-5.

29. Batra S, Perelman N, Luck LR, Shimada H, and Malik P. Pediatric Tumor Cells Express Erythropoietin and a Functional Erythropoietin Receptor that Promotes Angiogenesis and Tumour Cell Survival. Laboratory Investigation. 2003; 83: 1477-1487. 